J-DEPACE, Volume 02, Nomor 02, Desember 2019, Hal 136-149

Tersedia online di:http://jurnal.lpmiunvic.ac.id/index.php/jpkm

\title{
MENGOPTIMALILASI KETERBATASAN SUMBER DAYA UNTUK MEMAKSIMALKAN KEUNTUNGAN PENJUALAN ES KELAPA MUDA MENGGUNAKAN METODE SIMPLEKS DAN SOFTWARE POM-QM
}

\author{
Matheus Supriyanto Rumetna ${ }^{1 *}$, Tirsa Ninia Lina ${ }^{1}$, Okradi Sanggel ${ }^{1}$, Yulianti ${ }^{1}$, Ryan \\ Anugerah $^{1}$, Yulista Adi ${ }^{1}$, Joseph Eliza Lopulalan ${ }^{2}$ \\ ${ }^{1}$ Fakultas Ilmu Komputer, Universitas Victory Sorong \\ ${ }^{2}$ Fakultas Ilmu Sosial, Universitas Victory Sorong \\ *matheus.rumetna@gmail.com
}

\begin{abstract}
ABSTRAK
Es kelapa muda menjadi salah satu peluang usaha bagi kalangan menengah, namun keterbatasan sumber daya menjadi salah satu kesulitan yang dihadapi. Banyak usaha penjualan es kelapa muda yang ingin memaksimalkan keuntungan dari penjualan es kelapa muda. Masalah ini dapat diselesaikan dengan perhitungan menggunakan metode simpleks dan juga software POM-QM, karena dapat menjadi acuan bagi pelaku usaha penjual es kelapa muda dalam pengambilan keputusan. Berdasarkan hasil perhitungan, maka hasil keuntungan maksimum dari produksi es kelapa muda untuk setiap harinya yaitu sebesar Rp.171.171,-.
\end{abstract}

Kata kunci: metode simpleks, POM-QM, maximum profit

\section{Abstract}

Coconut ice is one of the business opportunities for the middle class, but limited resources are one of the difficulties encountered. Many businesses selling coconut ice who want to maximize profits from the sale of coconut ice. This problem can be solved by calculation using the simplex method and also POM-QM software, because it can be a reference for businesses coconut ice seller in decision making. Based on calculations, the results of the maximum profit from the production of coconut ice on a daily basis in the amount IDR 171.171, -

Keywords: simplex method, POM-QM, maximum profit 


\section{PENDAHULUAN}

Buah kelapa merupakan bagian paling penting dari tanaman kelapa karena mempunyai harga yang ekonomis dan gizi yang tinggi. Satu buah kelapa tua terdiri dari empat komponen utama, yaitu 35 persen sabut, 12 persen tempurung, 28 persen daging buah, dan 25 persen air kelapa. Daging buah kelapa selain nikmat disantap langsung (terutama kelapa yang masih muda), dapat diproses lebih lanjut seperti diolah menjadi santan atau minyak kelapa. Hal ini dikarenakan pada umumnya produk pertanian memiliki sifat yang mudah rusak di segala cuaca, maka produk pertanian harus segera dipasarkan dalam bentuk segar atau dapat diolah menjadi bahan pangan tahan simpan (Shantybio, 2010).

Buah kelapa muda merupakan salah satu tanaman tropis yang unik karena disamping komponen daging buahnya dapat langsung dikonsumsi, juga komponen air buahnya dapat langsung diminum. Keunikan ini ditunjang oleh sifat fisik dan komposisi daging dan air kelapa, sehingga produk ini sangat digemari konsumen baik orang dewasa maupun anakanak (Shantybio, 2010).

Air kelapa masih dapat dimanfaatkan secara optimal karena mengandung beberapa kelebihan diantaranya adalah kandungan zat gizinya yang tinggi meliputi protein, vitamin, mineral serta gula yang baik bagi tubuh. Kandungan gula pada air kelapa berkisar antara 1,7-2,6\%, terdiri dari glukosa, sukrosa, dan fruktosa. Kelebihan lain yang dimiliki air kelapa adalah dapat digunakan sebagai anti racun yaitu tanin, enzim pengurai racun dan kaya akan elektrolit sehingga cocok untuk dibuat minuman isotonik sebagai pengganti cairan tubuh yang keluar dan pengganti elektrolit saat dehidrasi untuk kasus diare (Shantybio, 2010).

Es kelapa muda merupakan minuman yang terbuat dari bahan kelapa muda, minuman ini sangat disukai karena memiliki rasa yang segar dan nikmat. Bahan baku pembuatan dari es kelapa muda ini alami sehingga banyak orang menyukai jenis minuman ini. Rasa air kelapa muda yang segar mampu menyehatkan tubuh dan mencegah terjadinya keracunan serta daging kelapa muda yang lembut memiliki banyak kandungan vitamin yang baik untuk tubuh.

Es kelapa muda dapat dijumpai di pedagang kaki lima sampai dengan restoran. Es kelapa muda berbahan dasar dari kelapa muda yang diserut kemudian diberi gula merah atau gula putih dan es ini digemari mulai anak kecil hingga orang dewasa. Minuman ini 
menjadi khas karena dilengkapi dengan susu cair, bahan tambahan tersebut yang membuat es ini menjadi nikmat.

Es kelapa muda juga termasuk golongan minuman yang masih sangat populer. Khasiat yang ada pada buah kelapa membuat banyak orang lebih memilih es kelapa muda untuk dijadikan minuman. Hal ini membuat peluang usaha dari es kelapa muda semakin diminati dan sangat bagus untuk dijalankan.

Oleh karena itu, para pelaku usaha es kelapa muda harus mampu merumuskan strategi yang tepat untuk menghadapi persaingan sehingga mampu bertahan. Dengan kondisi seperti ini, banyak usaha kecil yang harus berjuang untuk tetap melaksanakan aktivitas usaha. Penjual es kelapa muda milik Ibu Fatma yang beralamat di Jl. Km.10 masuk Kota Sorong adalah salah satu usaha kecil yang berusaha agar kelangsungan hidup dan usahanya dapat terus berkembang.

Demi menjaga kelangsungan dan berkembangnya usaha es kelapa muda diperlukan langkah-langkah untuk dapat mengalokasi bahan baku serta meningkatkan keuntungan (laba). Oleh sebab itu, diperlukan teknik atau suatu metode dalam menentukan kombinasi yang tepat dari produk yang dibuat serta kombinasi dari produk yang dihasilkan (Ong., et al.,2019; Rumetna, M.S., et al., 2019). Metode yang dapat digunakan yaitu Metode Simpleks yang merupakan bagian dari Program Linier.

Program Linier (PL) adalah metode optimasi untuk menemukan nilai optimum dari fungsi tujuan linier pada kondisi pembatasan-pembatasan (constraints) tertentu. Pembatasan-pembatasan tersebut biasannya keterbatasan yang berkaitan dengan sumber daya seperti (Rumetna Matheus Supriyanto., et al., 2019) :

1) Bahan mentah

2) Uang

3) Waktu

4) Tenaga kerja dll.

Persoalan PL dapat ditemukan pada berbagai bidang dan dapat digunakan untuk membantu membuat keputusan dalam memilih suatu alternatif yang paling tepat dan pemecahan yang paling baik (the best solution). Aplikasi PL biasanya digunakan untuk keperluan (Ngamelubun., et sl., 2019) :

1) Relokasi sumber daya,

2) Produksi campuran, 
Matheus Supriyanto Rumetna, dkk. Mengoptimalilasi Keterbatasan Sumber Daya Untuk Memaksimalkan Keuntungan Penjualan Es Kelapa Muda Menggunakan Metode Simpleks Dan

Software Pom-Qm

3) Keputusan investasi,

4) Perencanaan produksi,

5) Masalah trasportasi, logistik, dll.

Terdapat tiga elemen penting dalam PL (Rumetna., et al., 2019), yaitu:

1) Variabel keputusan (decision variables): $\mathrm{x}_{1}, \mathrm{x}_{2}, \ldots, \mathrm{x}_{\mathrm{n}}$ adalah variabel yang nilainilainya dipilih untuk dibuat keputusan.

2) Fungsi tujuan (objective function): $\mathrm{Z}=\mathrm{f}\left(\mathrm{x}_{1}, \mathrm{x}_{2}, \ldots, \mathrm{x}_{\mathrm{n}}\right)$ adalah fungsi yang akan dioptimasi (dimaksimumkan atau diminimumkan).

3) Pembatasan (constraints): $\mathrm{g}_{\mathrm{i}}\left(\mathrm{x}_{1}, \mathrm{x}_{2}, \ldots, \mathrm{x}_{\mathrm{n}}\right) \leq \mathrm{b}_{\mathrm{i}}$ adalah pembatasan-pembatasan yang harus dipenuhi.

Tujuan dari penggunaan PL khususnya metode simpleks serta software adalah untuk membantu Ibu Fatma dalam pengambilan keputusan, mempermudah menentukan dan menghitung keuntungan maksimum hasil penjualan es kelapa muda sehari-hari secara akurat.

\section{MASALAH}

Berdasarkan uraian pendahuluan, dirumuskan beberapa masalah yang dialami oleh para penjual es kelapa muda yaitu:

a. Menentukan package penjualan es kelapa muda.

b. Menentukan strategi penjualan es kelapa muda.

c. Proses perhitungan penjualan es kelapa muda yang cepat dan akurat untuk meningkatkan keuntungan dalam 1 (satu) bulan.

\section{METODE}

Pelaksanaan kegiatan ini menggunakan metode simpleks serta sofware POM-QM dalam perhitungan untuk menghasilkan sebuah pengambilan keputusan yang baik, juga menerapkan pendekatan pendidikan masyarakat seperti melakukan pelatihan untuk menghitung bersama keuntungan dari hasil penjualan buah pinang, serta sosialisasi yang bertujuan meningkatkan pemahaman serta kesadaran, dan sebagainya. Wawancara dan observasi digunakan dalam melakukan pengumpulan data. 
Matheus Supriyanto Rumetna, dkk. Mengoptimalilasi Keterbatasan Sumber Daya Untuk Memaksimalkan Keuntungan Penjualan Es Kelapa Muda Menggunakan Metode Simpleks Dan

Software Pom-Qm

\section{HASIL DAN PEMBAHASAN}

\subsection{Penerapan Metode Simpleks dan Software POM-QM}

Berdasarkan data yang didapat, diperoleh dua jenis rasa atau variabel, yaitu Es Kelapa Muda Gula Merah dan Es Kelapa Muda Gula Putih. Berikut rinciannya:

a. Untuk membuat 1 gelas Es Kelapa Muda Gula Merah bahan baku yang digunakan yaitu:

1) 1 buah kelapa dengan berat $1 \mathrm{~kg}$ (diubah menjadi satuan gram $=1.000 \mathrm{gr}$ )

2) 1.5 sendok kuah gula merah yang setara dengan 6 sendok makan (1 sendok makan gula merah cair $=15 \mathrm{gr}$ )

3) 250gr es batu

b. Sedangkan untuk membuat 1 gelas Es Kelapa Muda Gula Putih bahan baku yang digunakan yaitu:

1) 1 buah kelapa dengan berat $1 \mathrm{~kg}$ (diubah menjadi satuan gram $=1.000 \mathrm{gr}$ )

2) 1.5 sendok kuah gula putih yang setara dengan 6 sendok makan (1 sendok makan gula putih cair $=13.75 \mathrm{gr}$ )

3) 250gr es batu

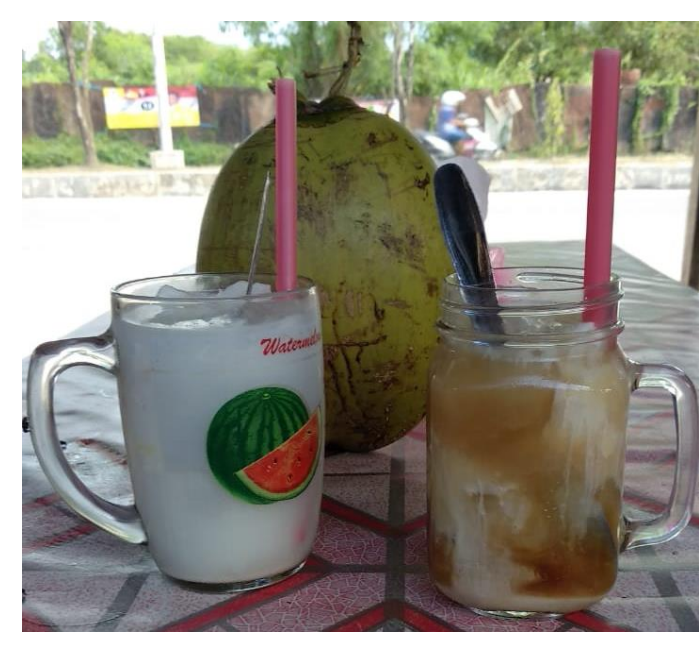

Gambar 1. Jenis Produk Es Kelapa Muda

Es Kelapa Muda Gula Merah dan Es Kelapa Muda Gula Putih dapat juga ditambahkan dengan susu kental manis, tergantung selera dari para konsumen.

Adapun keuntungan yang didapatkan dari dua jenis rasa ini, yaitu :

1) 1 gelas Es Kelapa Muda Gula Merah = Rp.10.000,-

2) 1 gelas Es Kelapa Muda Gula Putih = Rp.10.000,- 
Matheus Supriyanto Rumetna, dkk. Mengoptimalilasi Keterbatasan Sumber Daya Untuk Memaksimalkan Keuntungan Penjualan Es Kelapa Muda Menggunakan Metode Simpleks Dan

Software Pom-Qm

Sementara bahan baku yang disediakan untuk dua produk ini :

1) 100 buah kelapa muda (100.000gr)

2) 1 buah gula merah $(1 \mathrm{~kg}=1.000 \mathrm{gr})$

3) $1 / 2 \mathrm{~kg}$ gula putih $(500 \mathrm{gr})$

4) $5 \mathrm{~kg}$ es batu $(5.000 \mathrm{gr})$

Berdasarkan pengakuan Ibu Fatma, Es kelapa Muda Gula Merah dapat terjual hingga 10 gelas/hari sedangkan Es Kelapa Muda Gula Putih dapat terjual hingga 6 gelas/hari.

Penentuan formulasi berdasarkan data di atas, maka digunakan simbol X1, X2, dan $\mathrm{Z}$ dimana :

$\mathrm{X}_{1}=$ jumlah Es Kelapa Muda Gula Merah yang akan dibuat setiap hari

$\mathrm{X}_{2}=$ jumlah Es Kelapa Muda Gula Putih yang akan dibuat setiap hari

$\mathrm{Z}_{\max }=$ jumlah keuntungan Es kelapa Muda Gula Merah dan Es Kelapa Muda Gula Putih

Harapan dari Ibu Fatma adalah memperoleh keuntungan sebesar-besarnya dari kendala keterbatasan sumber daya yang dimiliki. Maka formulasi model matematisnya adalah :

$$
\text { Memaksimumkan } \mathrm{Z}=100.000 \mathrm{X}_{1}+60.000 \mathrm{X}_{2}
$$

Keterbatasan sumber daya dapat dibuat formulasi batasan-batasan sebagai berikut (lihat Tabel 1):

1) Kelapa yang digunakan untuk Es Kelapa Muda Gula Merah adalah 10kg/buah $\left(\mathrm{X}_{1}\right)$, sedangkan untuk Es Kelapa Muda Gula Putih adalah 6kg/buah $\left(\mathrm{X}_{2}\right)$. Kapasitas yang disediakan adalah $100 \mathrm{~kg} / \mathrm{buah}$.

2) Gula merah yang digunakan untuk Es Kelapa Muda Gula Merah adalah $0.9 \operatorname{kg}\left(\mathrm{X}_{1}\right)$. Kapasitas yang disediakan adalah $1 \mathrm{~kg}$.

3) Gula putih yang digunakan untuk Es Kelapa Muda Gula Putih adalah $0.495 \mathrm{~kg}\left(\mathrm{X}_{2}\right)$. Kapasitas yang disediakan adalah $0.5 \mathrm{~kg}$.

4) Es batu yang digunakan untuk Es Kelapa Muda Gula Merah adalah 2.5kg $\left(\mathrm{X}_{1}\right)$ dan es batu yang digunakan untuk Es Kelapa Muda Gula Putih $1.5 \mathrm{~kg}\left(\mathrm{X}_{2}\right)$. Kapasitas yang disediakan adalah $5 \mathrm{~kg}$. 
Matheus Supriyanto Rumetna, dkk. Mengoptimalilasi Keterbatasan Sumber Daya Untuk Memaksimalkan Keuntungan Penjualan Es Kelapa Muda Menggunakan Metode Simpleks Dan

Software Pom-Qm

Tabel 1. Bahan baku, Jenis Produk, Laba dan Stok

\begin{tabular}{|c|c|c|c|}
\hline \multirow{2}{*}{ Bahan baku } & \multicolumn{2}{|c|}{ Jenis produk } & \multirow{2}{*}{$\begin{array}{c}\text { Kapasitas } \\
\text { (penjualan) }\end{array}$} \\
\cline { 2 - 3 } & $\begin{array}{c}\text { Es Kelapa Muda } \\
\text { Gula Merah (gr) }\end{array}$ & $\begin{array}{c}\text { Es Kelapa Muda } \\
\text { Gula Putih (gr) }\end{array}$ & 100000 \\
\hline Kelapa & 10000 & 6000 & 1000 \\
\hline Gula Merah & 900 & 0 & 500 \\
\hline Gula Putih & 0 & 495 & 5000 \\
\hline Es Batu & 2500 & 1500 & \\
\hline Keuntungan & 100000 & 60000 & \\
\hline
\end{tabular}

Data pada Tabel 1 di atas dapat dibuat penyelesaian persoalan maksimum, langkahlangkah penyelesaiannya adalah sebagai berikut:

1) $10000 X_{1}+6000 X_{2} \leq 100000$

2) $900 X_{1}+\leq 1000$

3) $+495 \mathrm{X}_{2} \leq 500$

4) $2500 X_{1}+1500 X_{2} \leq 5000$

Fungsi tujuan diubah menjadi fungsi implisit yaitu menggeser elemen dari sebelah kanan ke sebelah kiri, sehingga fungsi tujuan ini menjadi:

$$
Z-35000 X_{1}-20000 X_{2}=0=>Z-100000 X_{1}-60000 X_{2}=0
$$

Fungsi batasan diubah dengan memberikan variable slack yang berguna untuk mengetahui batasan-batasan dalam kapasitas dengan menambah variabel tambahan menjadi:

1) $10000 \mathrm{X}_{1}+6.000 \mathrm{X}_{2} \leq 100.000$

$\Rightarrow 10000 X_{1}+6.000 X_{2}+X_{3}=100.000$

2) $900 \mathrm{X}_{1}+\quad \leq 1.000$

$$
\Rightarrow \quad 900 \mathrm{X}_{1}+\quad+\mathrm{X}_{4}=1.000
$$

3) $+495 \mathrm{X}_{2} \leq 500$

$\Rightarrow \quad 495 \mathrm{X}_{2} \quad+\mathrm{X}_{5}=500$

4) $2500 X_{1}+1500 X_{2} \leq 5000$

$\Rightarrow \quad 2500 X_{1}+1500 X_{2}+X_{6}=5000$

Persamaan-persamaan di atas disusun dalam tabel formulasi (lihat Tabel 2) berikut. 
Matheus Supriyanto Rumetna, dkk. Mengoptimalilasi Keterbatasan Sumber Daya Untuk Memaksimalkan Keuntungan Penjualan Es Kelapa Muda Menggunakan Metode Simpleks Dan

Software Pom-Qm

Tabel 2. Formulasi

\begin{tabular}{|c|c|c|c|c|c|c|c|c|}
\hline $\begin{array}{c}\text { Variabel } \\
\text { Dasar }\end{array}$ & $\mathrm{Z}$ & $\mathrm{X}_{1}$ & $\mathrm{X}_{2}$ & $\mathrm{X}_{3}$ & $\mathrm{X}_{4}$ & $\mathrm{X}_{5}$ & $\mathrm{X}_{6}$ & $\mathrm{NK}$ \\
\hline $\mathrm{Z}$ & 1 & -100000 & -60000 & 0 & 0 & 0 & 0 & 0 \\
\hline $\mathrm{X}_{3}$ & 0 & 10000 & 6000 & 1 & 0 & 0 & 0 & 100000 \\
\hline $\mathrm{X}_{4}$ & 0 & 900 & 0 & 0 & 1 & 0 & 0 & 1000 \\
\hline $\mathrm{X}_{5}$ & 0 & 0 & 495 & 0 & 0 & 1 & 0 & 500 \\
\hline $\mathrm{X}_{6}$ & 0 & 2500 & 1500 & 0 & 0 & 0 & 1 & 5000 \\
\hline
\end{tabular}

Setelah mengetahui jenis produksi, rincian bahan baku serta laba yang dihasilkan kemudian dari data tersebut diubah dalam bentuk persamaan (formulasi) lalu dengan menggunakan software POM-QM data tersebut akan diolah untuk mengetahui keuntungan per hari dari hasil penjualan es kelapa muda. Berikut langkah-langkah pemecahan PL menggunakan software POM-QM :

1) Saat program aktif maka akan otomatis dialihkan pada menu modul, untuk persoalan PL, maka pilih modul Linear Programming (lihat Gambar 2 dan 3).

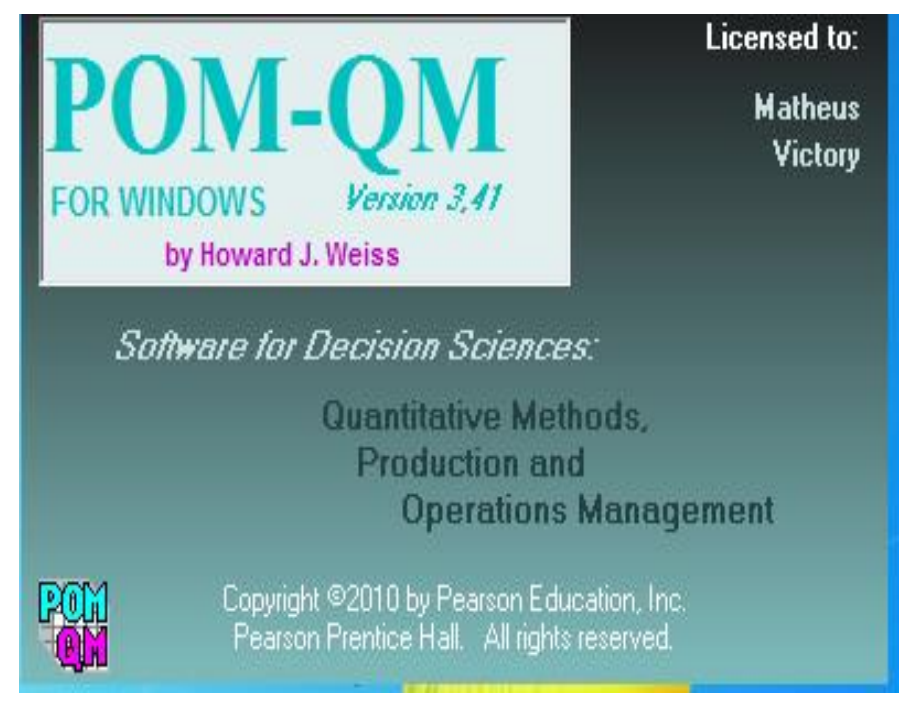

Gambar 2. Tampilan Awal POM-QM for Windows versi 3.0 
Matheus Supriyanto Rumetna, dkk. Mengoptimalilasi Keterbatasan Sumber Daya Untuk Memaksimalkan Keuntungan Penjualan Es Kelapa Muda Menggunakan Metode Simpleks Dan

Software Pom-Qm

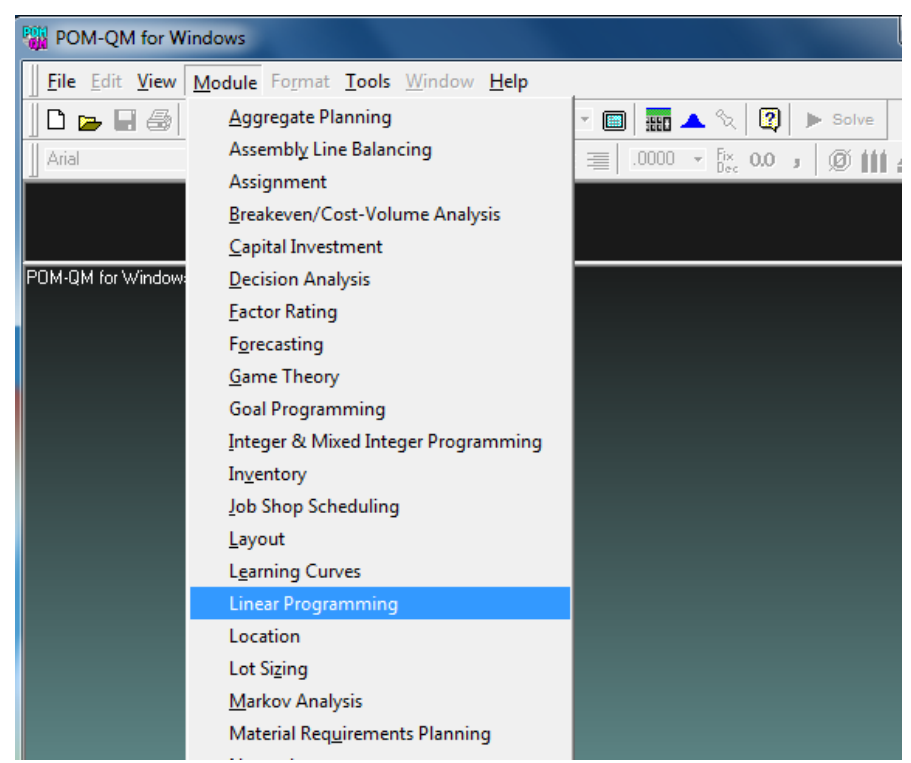

Gambar 3. Tampilan Pilihan Modul Pada POM-QM for Windows

2) Kemudian untuk membuat file baru, pilih File $\rightarrow$ New (lihat Gambar 4).

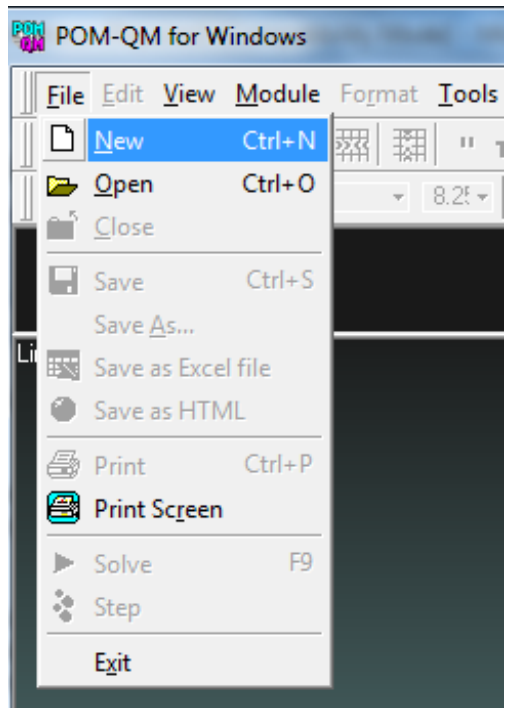

Gambar 4. Tampilan Membuat File Baru

3) Kemudian memberi masukan pada file untuk data yang akan diolah, seperti judul, jumlah kendala/batasan, jumlah variabel keputusan, nama baris, dan nama kolom. Pada program ini tidak diperlukan lagi memasukkan pembatasan non-negatif (lihat Gambar 5). 
Matheus Supriyanto Rumetna, dkk. Mengoptimalilasi Keterbatasan Sumber Daya Untuk Memaksimalkan Keuntungan Penjualan Es Kelapa Muda Menggunakan Metode Simpleks Dan

Software Pom-Qm

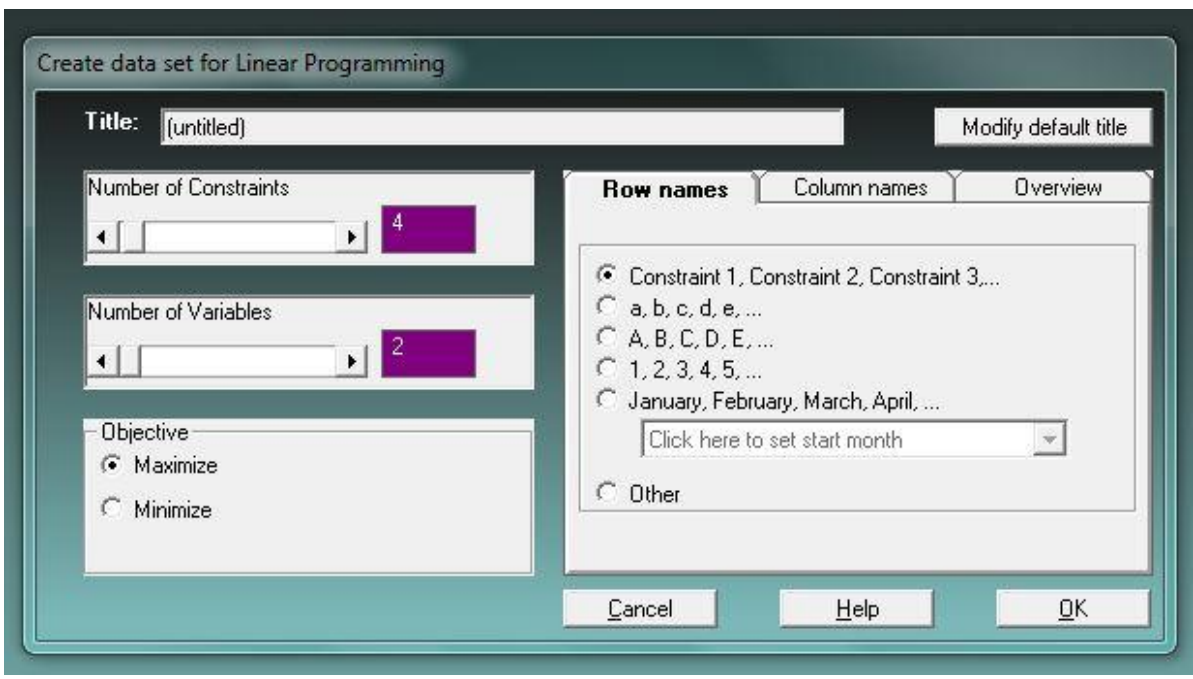

Gambar 5. Form Masukkan Data

4) Setelah itu memasukkan data produksi ke dalam kolom yang telah disediakan (lihat Gambar 6).

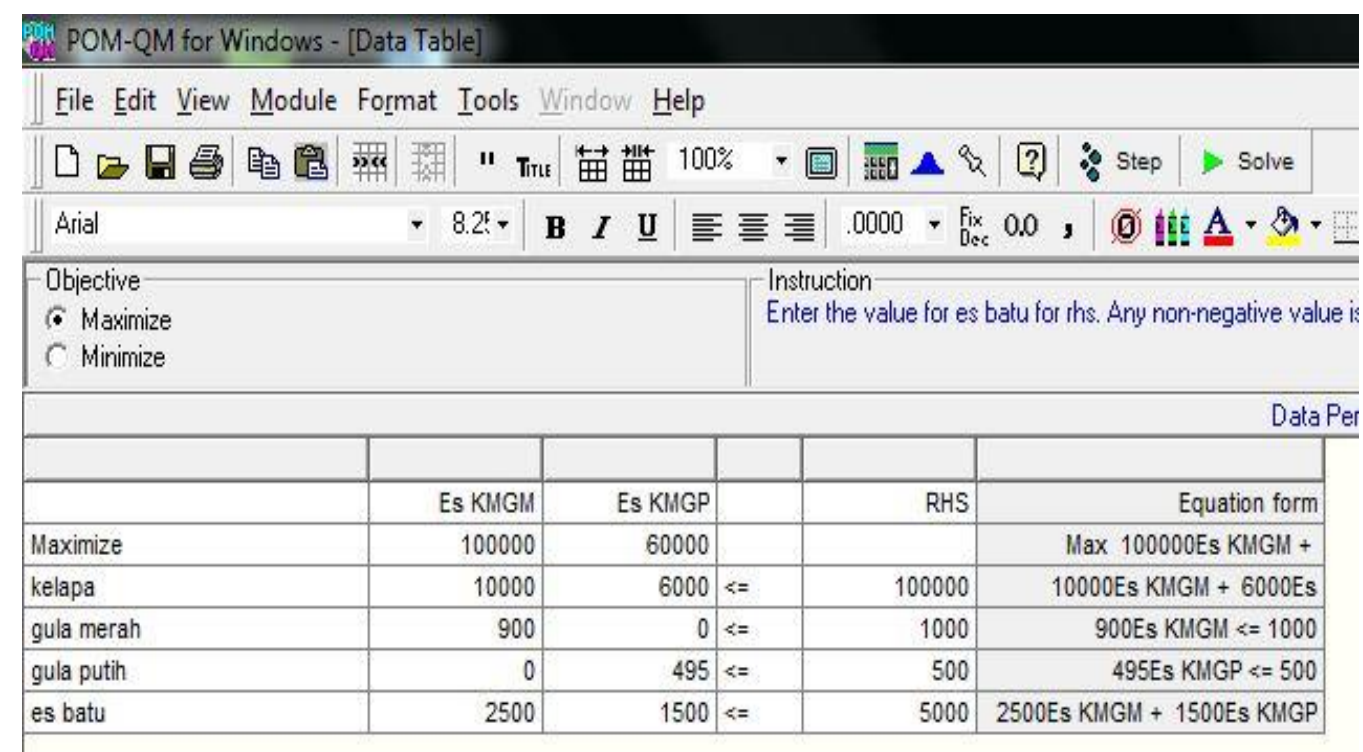

Gambar 6. Form Masukan Data Produksi

5) Setelah data selesai dimasukkan kemudian pilih tombol solve lalu pilih menu Literations. Maka akan diperoleh solusi pemecahan persoalan LP dengan metode Simplex (lihat Gambar 7 dan 8). 
Matheus Supriyanto Rumetna, dkk. Mengoptimalilasi Keterbatasan Sumber Daya Untuk Memaksimalkan Keuntungan Penjualan Es Kelapa Muda Menggunakan Metode Simpleks Dan

Software Pom-Qm

\begin{tabular}{|c|c|c|c|c|c|c|c|c|}
\hline \# Itera & & & & & & & \multicolumn{2}{|r|}{ 回 } \\
\hline \multicolumn{9}{|c|}{ (untitled) Solution } \\
\hline $\mathrm{Cj}$ & $\begin{array}{r}\text { Basic } \\
\text { Variables }\end{array}$ & $\begin{array}{r}100000 \\
\mathrm{X} 1\end{array}$ & $\begin{array}{r}60000 \\
\times 2\end{array}$ & $\begin{array}{r}0 \\
\text { slack } 1\end{array}$ & $\begin{array}{r}0 \\
\text { slack } 2\end{array}$ & slack 30 & $\begin{array}{r}0 \\
\text { slack } 4\end{array}$ & Quantity \\
\hline \multicolumn{9}{|c|}{ Iteration 1} \\
\hline & $c j-z j$ & 100.000 & 60.000 & 0 & 0 & 0 & 0 & \\
\hline 0 & slack 1 & 10.000 & 6.000 & 1 & 0 & 0 & 0 & 100.000 \\
\hline 0 & slack 2 & 900 & 0 & 0 & 1 & 0 & 0 & 1.000 \\
\hline 0 & slack 3 & 0 & 495 & 0 & 0 & 1 & 0 & 500 \\
\hline 0 & slack 4 & 2.500 & 1.500 & 0 & 0 & 0 & 1 & 5.000 \\
\hline \multicolumn{9}{|c|}{ tteration 2} \\
\hline & $c j-z j$ & 0 & 60.000 & 0 & $-111,1111$ & 0 & 0 & \\
\hline 0 & slack 1 & 0 & 6.000 & 1 & $-11,1111$ & 0 & 0 & \\
\hline 100000 & $\mathrm{X} 1$ & 1 & 0 & 0 & 0,0011 & 0 & 0 & 1,1111 \\
\hline 0 & slack 3 & 0 & 495 & 0 & 0 & 1 & 0 & 500 \\
\hline 0 & slack 4 & 0 & 1.500 & 0 & $-2,7778$ & 0 & 1 & $2.222,2222$ \\
\hline \multicolumn{9}{|c|}{ Iteration 3} \\
\hline & $c j-z j$ & 0 & 0 & 0 & $-111,1111$ & $-121,2121$ & 0 & \\
\hline 0 & slack 1 & 0 & 0 & 1 & $-11,1111$ & $-12,1212$ & 0 & \\
\hline 100000 & $\mathrm{X} 1$ & 1 & 0 & 0 & 0,0011 & 0 & 0 & 1,1111 \\
\hline 60000 & $\mathrm{x} 2$ & 0 & 1 & 0 & 0 & 0,002 & 0 & 1,0101 \\
\hline 0 & slack 4 & 0 & 0 & 0 & $-2,7778$ & $-3,0303$ & 1 & 707,0707 \\
\hline & & & & & & & & \\
\hline
\end{tabular}

Gambar 7. Tampilan Pemecahan Masalah

\begin{tabular}{|l|r|r|}
\hline Solution list & (untitled) Solution \\
\hline Variable & Status & Value \\
\hline X1 & Basic & 1,1111 \\
\hline X2 & Basic & 1,0101 \\
\hline slack 1 & Basic & 82828,28 \\
\hline slack 2 & NONBasic & 0 \\
\hline slack 3 & NONBasic & 0 \\
\hline slack 4 & Basic & 707,0707 \\
\hline Optimal Value $(Z)$ & & 171717,2 \\
\hline \hline
\end{tabular}

Gambar 8. Tampilan Solusi Akhir

Hasil analisis menunjukkan bahwa penerapan PL dengan menggunakan software POM-QM dalam optimasi penjual es kelapa muda dapat membantu dalam menghitung keuntungan maksimum dari keterbatasan sumber daya yang dimiliki. Keuntungan maksimal yang dapat diperoleh ibu Fatma yaitu sebesar Rp.171.717,- per produksi es kelapa muda untuk setiap harinya, hal ini dapat dilihat pada Gambar 8. 
Matheus Supriyanto Rumetna, dkk. Mengoptimalilasi Keterbatasan Sumber Daya Untuk Memaksimalkan Keuntungan Penjualan Es Kelapa Muda Menggunakan Metode Simpleks Dan

Software Pom-Qm

\subsection{Pelatihan serta Sosialisasi Hasil Penerapan Metode Simpleks dan Software POM- QM}

Implementasi dari penerapan metode simpleks dan software POM-QM untuk menghitung keuntungan maksimum yang diperoleh dari penjualan es kelapa muda dilakukan dengan cara sosialisasi. Sosialisasi ini diharapkan dapat membantu para penjual es kelapa muda dalam menentukan jumlah package penjualan, serta menentukan strategi penjualan buah pinang, sehingga dapat meraih keuntungan yang maksimal. Kegiatan sosialisasi ini dapat dilihat pada Gambar 9.
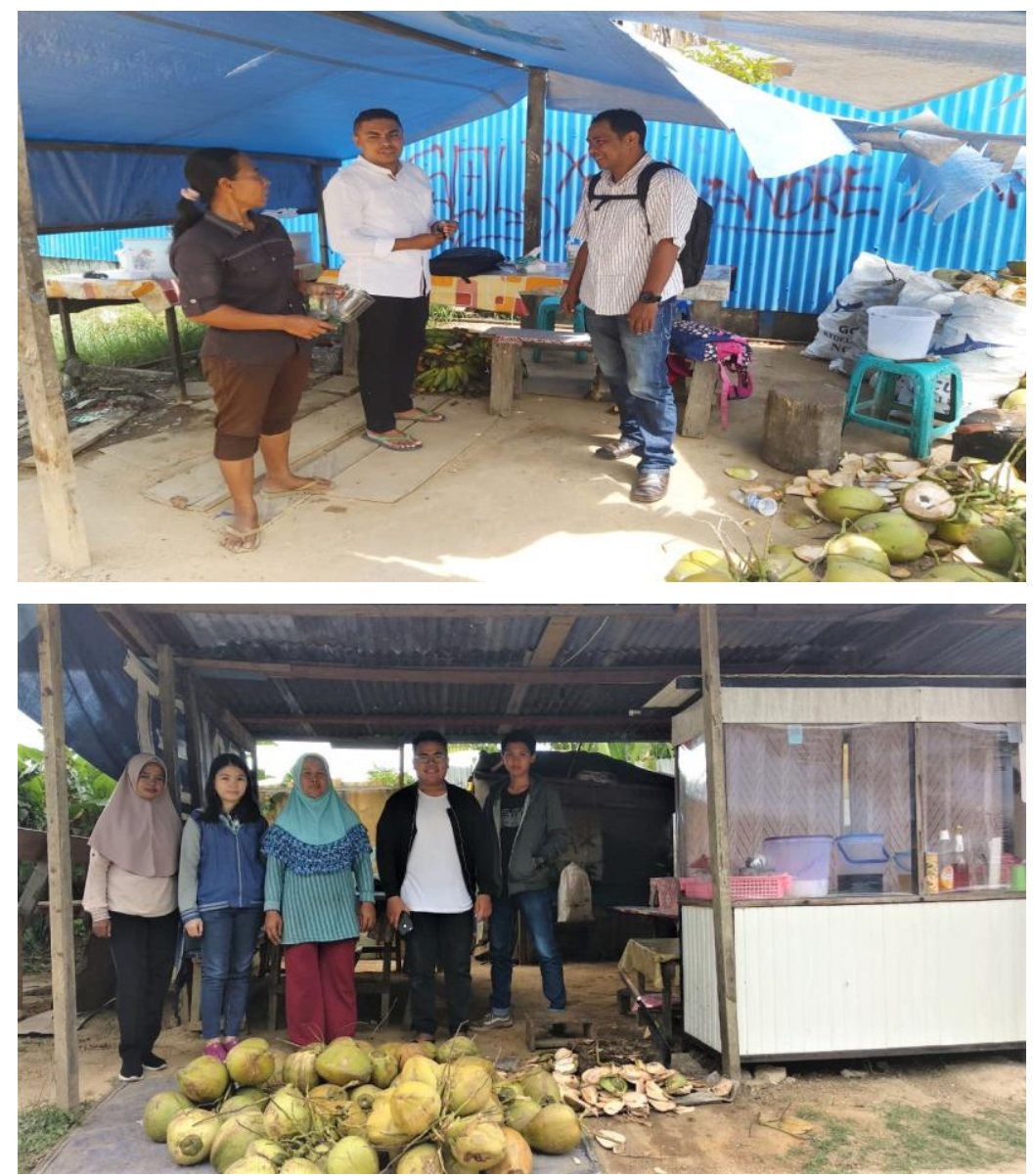

Gambar 9. Kegiatan Sosialisasi Kepada Pelaku Usaha Es Kelapa Muda

Kegiatan pelatihan serta sosialisasi ini dilakukan pada tanggal 30 November 2019, pada pukul 15.00-17.00 WIT. Kegiatan ini diikuti oleh para pelaku usaha es kelapa muda. 
Matheus Supriyanto Rumetna, dkk. Mengoptimalilasi Keterbatasan Sumber Daya Untuk Memaksimalkan Keuntungan Penjualan Es Kelapa Muda Menggunakan Metode Simpleks Dan

Software Pom-Qm

\section{KESIMPULAN}

Es kelapa muda termasuk golongan minuman yang sangat populer. Khasiat yang ada pada buah kelapa membuat banyak orang lebih memilih es kelapa muda untuk dijadikan minuman. Hal ini membuat peluang usaha dari es kelapa muda semakin diminati dan sangat bagus untuk dijalankan. Oleh karena itu, para pelaku usaha es kelapa muda harus mampu merumuskan strategi yang tepat untuk menghadapi persaingan sehingga mampu bertahan. Dengan kondisi seperti ini banyak usaha kecil yang harus berjuang untuk tetap melaksanakan aktifitas usaha.

Untuk menjaga kelangsungan dan berkembangnya usaha es kelapa muda diperlukan teknik atau suatu metode dalam menentukan kombninasi yang tepat dari produk yang di buat serta kombinasi dari produk yang dihasilkan. Penerapan metode simpleks dan software POM-QM menjadi salah satu solusi untuk menyelesaikan permasalahan optimasi penjualan es kelapa muda, sehingga dapat membantu memaksimalkan keuntungan dari keterbatasan sumber daya yang dimiliki oleh Ibu Fatma dan para pelaku usaha penjual es kelapa muda lainnya.

\section{DAFTAR PUSTAKA}

Ngamelubun Vinsentius, Zulkarnain Sirajuddin Muhammad, Lundi Lucky Salambauw Rovalino, Imanuhua Jody, Edmar Fossa Fedinan, Maha Leonardo, Rumetna Matheus Supriyanto, Lina Tirsa Ninia. (2019). Optimalisasi Keuntungan Menggunakan Metode Simpleks Pada Produksi Batu Tela. Jurnal Riset Komputer (JURIKOM). Volume 6 Nomor 5 Oktober 2019 : 484-491 https://www.ejurnal.stmikbudidarma.ac.id/index.php/jurikom/article/view/1494 diakses tanggal 1 Desember 2019

Ong Rico, Maran Alfionita, Lapik Ardianto, Andita Dimas, Kadir Muhammad Fitra, Kindangen Ricky, Latul Velly, Rumetna Matheus Supriyanto, Lina Tirsa Ninia. (2019). Maksimalisasi Keuntungan Pada Usaha Dagang Martabak Sucipto Menggunakan Metode Simpleks Dan POM-QM. Jurnal Riset Komputer (JURIKOM). Volume 6 Nomor 4 Agustus 2019 : 434-441 https://ejurnal.stmikbudidarma.ac.id/index.php/jurikom/article/view/1350 diakses tanggal 1 Desember 2019

Rumetna Matheus Supriyanto, Lina Tirsa Ninia, Paknawan Razni, Filemon, Siwalette Bryan, Andriano, Deviana Rezty. (2019). Penerapan Metode Simpleks Untuk Menghasilkan Keuntungan Maksimum Pada Penjual Buah Pinang. Journal Of Dedication To Papua Community (J-DEPACE). Volume 2 Nomor 1 Juni 2019 : 75-86 
Matheus Supriyanto Rumetna, dkk. Mengoptimalilasi Keterbatasan Sumber Daya Untuk Memaksimalkan Keuntungan Penjualan Es Kelapa Muda Menggunakan Metode Simpleks Dan Software Pom-Qm

http://jurnal.lpmiunvic.ac.id/index.php/jpkm/article/view/17 diakses tanggal 1 Desember 2019

Rumetna M. S., Lina T. N., Simarmata L., Parabang L., Joseph A., and Batfin Y. (2019). Pemanfaatan POM-QM Untuk Menghitung Keuntungan Maksimum UKM Aneka Cipta Rasa (ACR) Menggunakan Metode Simpleks, Seminar Nasional GEOTIK. 2019

: 12-22. https://publikasiilmiah.ums.ac.id/xmlui/handle/11617/10785 diakses tanggal 1 Desember 2019

Shantybio, (2010). Nata De Coco Yang Kaya Serat BiologyMikrobiologi. http:// Transdigit.com diakses tanggal 25 November 2019 